\title{
Correction to: Human umbilical cord-derived mesenchymal stem cells improve the function of liver in rats with acute-on-chronic liver failure via downregulating Notch and Stat $1 /$ Stat3 signaling
}

Yulin $\mathrm{He}^{1,2+}$, Xingrong Guo ${ }^{1,2+}$, Tingyu Lan ${ }^{1,2,3,4}$, Jianbo Xia ${ }^{5}$, Jinsong Wang ${ }^{6}$, Bei Li ${ }^{1,2}$, Chunyan Peng ${ }^{1,2}$, Yue Chen ${ }^{2,4}$, Xiang $\mathrm{Hu}^{6^{*}}$ and Zhongji Meng ${ }^{1,2,4^{*}}$

\section{Correction to: Stem Cell Research \& Therapy (2021) 12:396} https://doi.org/10.1186/s13287-021-02468-6

The original article [1] contained incorrect affiliation numbers for each author which have since been corrected.

\section{Author details}

${ }^{1}$ Institute of Biomedical Research, Hubei Clinical Research Center for Precise Diagnosis and Treatment of Liver Cancer, Taihe Hospital, Hubei University of Medicine, Shiyan 442000, Hubei, China. ${ }^{2}$ Hubei Key Laboratory of Embryonic Stem Cell Research, Shiyan 442000, Hubei, China. ${ }^{3}$ Postgraduate Training Basement of Jinzhou Medical University, Taihe Hospital, Hubei University of Medicine, Shiyan 442000, Hubei, China. ${ }^{4}$ Department of Infectious Diseases, Taihe Hospital, Hubei University of Medicine, Shiyan 442000, Hubei, China. ${ }^{5}$ Department of Laboratory Medicine, Maternal and Child Health Hospital of Hubei Province, Wuhan 430070, Hubei, China. ${ }^{6}$ Shenzhen Beike Biotechnology Research Institute, Nanshan District, Shenzhen 518057, China.
Published online: 07 February 2022

\section{Reference}

1. He Y, et al. Human umbilical cord-derived mesenchymal stem cells improve the function of liver in rats with acute-on-chronic liver failure via downregulating Notch and Stat1/Stat3 signaling. Stem Cell Res Ther. 2021;12:396. https://doi.org/10.1186/s13287-021-02468-6.

\section{Publisher's Note}

Springer Nature remains neutral with regard to jurisdictional claims in published maps and institutional affiliations.

The original article can be found online at https://doi.org/10.1186/s13287021-02468-6.

\footnotetext{
*Correspondence: huxiang@beike.cc; zhongji.meng@163.com

${ }^{\dagger}$ Yulin He and Xingrong Guo contributed equally to this work.

${ }^{1}$ Institute of Biomedical Research, Hubei Clinical Research Center

for Precise Diagnosis and Treatment of Liver Cancer, Taihe Hospital, Hubei

University of Medicine, Shiyan 442000, Hubei, China

${ }^{6}$ Shenzhen Beike Biotechnology Research Institute, Nanshan District, Shenzhen 518057. China

Full list of author information is available at the end of the article
} permits use, sharing, adaptation, distribution and reproduction in any medium or format, as long as you give appropriate credit to the original author(s) and the source, provide a link to the Creative Commons licence, and indicate if changes were made. The images or other third party material in this article are included in the article's Creative Commons licence, unless indicated otherwise in a credit line to the material. If material is not included in the article's Creative Commons licence and your intended use is not permitted by statutory regulation or exceeds the permitted use, you will need to obtain permission directly from the copyright holder. To view a copy of this licence, visit http://creativecommons.org/licenses/by/4.0/. The Creative Commons Public Domain Dedication waiver (http://creativeco mmons.org/publicdomain/zero/1.0/) applies to the data made available in this article, unless otherwise stated in a credit line to the data. 